\title{
Third-Degree Burn
}

National Cancer Institute

\section{Source}

National Cancer Institute. Third-Degree Burn. NCI Thesaurus. Code C76132.

An injury that includes all skin layers into the subcutaneous tissue due to chemical,

friction, radiation or thermal exposure. The affected area appears dry and thickened; damage to nerve endings usually renders the wound painless. 